\title{
Severe Neurological Manifestation from Jatropha curcas (Mbono Kaburi) Poisoning in 5 Years 0ld: A Case Report
}

\author{
Matei Mselle1,2*, Aisa Shayo,,2, Ronald Mbwasi1,2, Phillip Mrindoko1,2, Elise Kimambo1,2, \\ Arnold Likiliwike1,2, Lucy Frisch ${ }^{1}$, Elton Meleki' ${ }^{2}$, Zaituni Hatibu', Nyemo Peter ${ }^{1,2}$, Ally Iman', \\ Faith Mosha1,2, Beatrice Maringo 1,2, Ikupa Minga1, Deborah Mchaile1,2 \\ ${ }^{1}$ Department of Paediatrics and Child Health, Kilimanjaro Christian Medical University College, Moshi, Tanzania \\ ${ }^{2}$ Department of Paediatrics and Child Health, Kilimanjaro Christian Medical Centre, Moshi, Tanzania \\ Email: ^mathewmselle90@gmail.com, aisa.shayo@gmail.com, ronald.mbwasi@gmail.com, philipmrindoko1@gmail.com, \\ elisekimambo@gmail.com, arnolddav23@gmail.com, lucyfrisch@yahoo.com, ellierolland@gmail.com, \\ zaitunihatibu.zh@gmail.com,nyemopk@gmail.com, allyiman05@gmail.com,drfaithmosha@gmail.com, \\ beatricesia.maringo@gmail.com,iminga2003@gmail.com,maggyjossy@gmail.com,deborahsia@hotmail.co.uk
}

How to cite this paper: Mselle, M., Shayo, A., Mbwasi, R., Mrindoko, P., Kimambo, E., Likiliwike, A., Frisch, L., Meleki, E., Hatibu, Z., Peter, N., Iman, A., Mosha, F., Maringo, B., Minga, I. and Mchaile, D. (2022) Severe Neurological Manifestation from Jatropha curcas (Mbono Kaburi) Poisoning in 5 Years Old: A Case Report. Open Access Library Journal, 9: e8028. https://doi.org/10.4236/oalib.1108028

Received: September 29, 2021

Accepted: January 4, 2022

Published: January 7, 2022

Copyright $\odot 2022$ by author(s) and Open Access Library Inc.

This work is licensed under the Creative Commons Attribution International License (CC BY 4.0).

http://creativecommons.org/licenses/by/4.0/ (c) (i) Open Access

\begin{abstract}
Background: Jatropha curcas belongs to the Euphorbiaceae family and is found in the coastal areas of tropics. The leaves, fruits and seeds of the plant are used for various ailments. Not only there are few reported cases of its poisoning in the paediatric age group but also rarely reported to cause neurological manifestation even in adult population. We present a case of a 5 years old that presented with severe acute neurological manifestation soon after ingestion of the seeds of Jatropha curcas. The patient was managed symptomatic and supportive with complete recovery in $48 \mathrm{hrs}$. Case Presentation: 5 years old male child was referred to our hospital $7 \mathrm{hrs}$ after taking Jatropha curcas fruit. He presented with history of loss of consciousness for 2 hours and 3 episodes of convulsions. On examination had Glasgow Coma Score (GCS) of $8 / 15$, and pinpointed pupils, with no obvious neurological deficit. We managed him conservatively, with active seizure control, IV fluid, and precautious IV Ceftriaxone due to clinical mimicry of meningitis. The patient completely recovered and was discharged on the third day. Conclusion: Jatropha curcas poisoning is less reported in our region and our country. Based on our case report, it does not only present with gastrointestinal manifestation but also neurological manifestation which may be confusing in low resource setting where the diagnostics may not be available or affordable to rule out other intracranial manifestations due to low social economic status. This is the first case report in our setup and country with neurological manifestation.
\end{abstract}




\section{Subject Areas}

Internal Medicine, Neurology, Pediatrics

\section{Keywords}

Jatropha curcas Poisoning, Neurological Manifestation, Tanzania

\section{Background}

Jatropha curcas is a common plant found all over the world. The name is derived from Greek (iatros = physician and trophe = nutrition), hence the common name physic nut [1]. The other common names are Jungle Erandi, Ratanjot, Bagranda, purging nut tree and Barbados nut tree [2], also known as mbono kaburi in Swahili language and michakaburi in local language. Children are regularly exposed to toxic plants and usually poisoned when plants are mistaken for common, edible plants e.g., Jatropha curcas is often mistaken for nuts [3] [4] [5] [6] [7]. There are fewer datasets on paediatric poisoning from developing countries than from developed countries, likely due to underreporting of cases and lack of proper data management systems [8]. It's even less reported and observed in our region. Gastrointestinal system manifestations are commonly reported, including vomiting, diarrhoea, and abdominal pain [9].

We present a case report of a 5-year-old boy with acute neurological manifestation from Jatropha curcus poisoning from tertiary hospital in Northern Tanzania.

\section{Case Presentation}

A 5-year-old boy was referred to our hospital due to loss of consciousness for one hour and three episodes of convulsion. This child was well until 7 hrs prior to admission where he was found unconscious in the farm, after being reported by his brother to ingest fruits with black nuts of locally known as mchakaburi. His brother developed severe vomiting and recovered in a nearby health centre, but our patient was reported to have lost consciousness for almost one hour, and after regaining consciousness he was reported to develop one episode of tonic-clonic convulsion associated with tongue biting, followed by deep sleep. At the primary health centre he was given normal saline and Phenobarbitone then referred to our hospital. On arrival he developed two episodes of convulsions tonic-clonic in nature and was loaded with Diazepam and maintained with Phenobarbitone.

The fruits was brought by the parent and identified as Jatropha carcus (Figure 1). This was his very first admission, and was reported to have no any history of chronic illness or trauma.

Examination findings on admission, he was semiconscious with GCS of 8/15, normal posture, nutritionally well, no scalp swelling or bruises, no bleeding per 

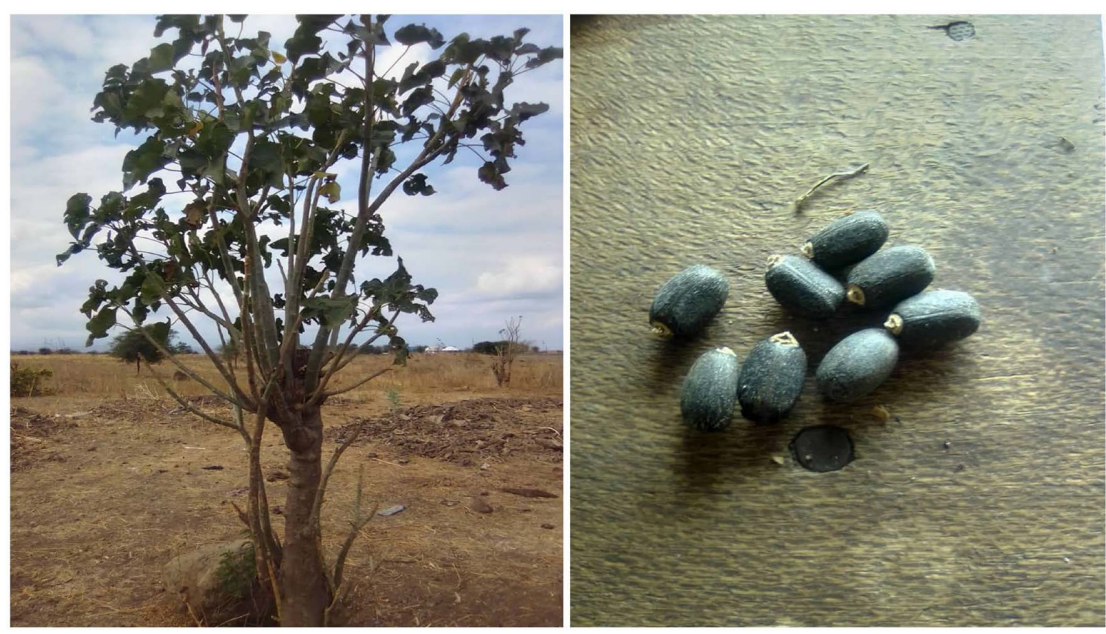

Figure 1. Picture of the tree and nuts sent by parent of the child.

ENT, oxygen saturation $98 \%$ in room air. His temperature was $38^{\circ} \mathrm{C}$, respiratory rate was 31 breaths per minute, pulse rate of 140 beats per minute. His random blood glucose on admission was $7.2 \mathrm{mmol} / \mathrm{l}$. On neurological examination he was semiconscious, with pinpointed pupils, no lateralization, negative signs of meningeal irritation and normal funduscopic findings.

\section{Investigation findings}

Blood workup showed a normal serum sodium level of $140 \mathrm{mmol} / \mathrm{l}$, potassium of $4.35, \mathrm{mmol} / \mathrm{l}$, urea of $2.43 \mathrm{mmol} / \mathrm{l}$, serum creatinine of $36 \mu \mathrm{mol} / \mathrm{l}$, slightly elevated AST $50 \mathrm{U} / \mathrm{l}$ and normal of ALT $25 \mathrm{U} / \mathrm{l}$. He had leukocyte count of $11.90 \times$ $10^{9} / \mathrm{L}$, haemoglobin of $10.7 \mathrm{~g} / \mathrm{dl}$, and platelets of $480 \times 10^{9} / \mathrm{L}$ Serology for HIV was negative.

\section{Diagnosis and management}

We reached a diagnosis of Herbal Neurotoxicity, differential diagnosis of meningitis. The child was started on maintenance IV fluids of $1400 \mathrm{mls}$ of Ringers Lactate alternating with Dextrose Normal Saline (DNS), as maintenance since the child was kept nil per oral, empirical IV Ceftriaxone $900 \mathrm{mg} 12$ hourly due to clinical mimicry of meningitis, Diazepam loading of $5.4 \mathrm{mg}$ IV if seizure reoccur and Phenobarbitone $60 \mathrm{mg}$ nocte, and was nursed in lateral recumbent position in the paediatric intensive care unit to avoid risk of aspiration if he vomits. Urethral catheter was inserted with good urine output. Patient was planned for Brain CT scan to rule out any intracranial abnormality, but unfortunately due to financial constraints of the parents it was not done. Within the first 24 hours the child had marked improvement in terms of level of consciousness from 8/15 to $15 / 15$, had no any vital instability, and could walk and eat by himself. On the second day he was transferred out to general ward, of which antibiotics were stopped and on the third day the child was discharged with no any marked neurological deficit.

\section{Discussion}

The seeds of $J$. curcas are toxic to both humans and animals excluding their use 
in foodstuffs. Despite its medicinal uses, the plant is toxic due to presence of toxalbumin called curcin, ricin and cyanic acid, related to ricinoleic acid. Ricin has been shown to exhibit both cardiotoxic and haemolytic effects. Though all parts of the plant are poisonous, seeds have the highest concentration of ricin and thus very poisonous [10]. Toxicity of the seed is attributed predominantly to the phorbol-type diterpene esters which they contain at high concentrations. Previous studies on leaves of this plant have investigated the isolation of flavonoids, sterols, polyprenols, besides saprophytic fungal activity, larvicidal activity, and molluscicidal activity [11].

J. curcas seeds were shown to have inflammatory effect on study of mice and effects on the nervous system were founded as stereotypes and Straub tail [12].

Although GI manifestation are commonly reported, it's sometimes associated with neurological or cardiovascular signs, and hepatic or renal disorders; these were generally interpreted as complications of severe gastroenteritis, although direct toxic effects could not be formally excluded. In most cases, simple supportive measures were sufficient to ensure complete recovery within 24 - 48 hours [13]. May present also with features that resemble organophosphate poisoning, where in clinical setting may stand as an important differential diagnosis [14]. In our patient, he primarily presented with neurological manifestation which is rarely seen in this poisoning and has never been reported in our country.

Treatment is essentially symptomatic and supportive. In all cases of ingestion or suspected ingestion, if the child is conscious; induce emesis within 1 - 2 hours of ingestion with Ipecac syrup or perform gastric lavage. There is no specific antidote. Specific therapy may be indicated for haemorrhagic gastrointestinal damage, skeletal muscle and gastrointestinal spasm, excessive salivary secretions and haemoglobinuria. After substantial exposures to toxalbumin containing plants, minimum observation period of up to 8 hours is advised. IV fluids and electrolyte as necessary to restore and maintain fluid and electrolyte balance is to be given. Monitoring of renal functions and alkalinisation of urine is done to minimize effects of haemoglobinuria. Treatment of haemorrhagic gastro-intestinal damage is like that of peptic ulceration. Signs of central nervous system depression are looked for and assisted ventilation is initiated, if necessary [15]. In our patient we gave IV fluids and empirical antibiotics as CNS infection could not be ruled out and within 48 hours he recovered.

Although most of the Jatropha curcas poisoning clinical manifestation are selflimiting, precaution and proper symptomatic approach has to be established as if left untreated can simply become life threatening to the victim.

\section{Conclusion}

Jatropha curcas poisoning is less reported in our region and our country in general. Worldwide neurological manifestation from this poison is also less reported. It can easily be confused with CNS infection which may be hard to diagnose due low socio economic status of our patients and also low resource setting which 
may not have diagnostics available. This is the first case report in our setup and country with neurological manifestation.

\section{Consent}

Verbal informed consent was obtained from the patient's Father for publication for this case report.

\section{Authors' Contributions}

MM, AS, RM and DNM conceptualised and prepared the manuscript PEM, FM, EK, AL, DNM, ZH, IM, ERM, NP, AI, LF, FM, BM and MJ reviewed the patient medical records. All authors have read and approved the final manuscript.

\section{Acknowledgements}

The authors would like to thank the child's Father for permission to share her child's medical history for educational purposes and publication.

\section{Conflicts of Interest}

The authors declare they have no competing interests.

\section{References}

[1] Shah, V. and Sanmukhani, J. (2010) Five Cases of Jatropha curcas Poisoning. Journal of the Association of Physicians of India, 58, 245-246.

[2] Barceloux, D.G. (2008) Barbados Nut (Jatropha curcas L.) Medical Toxicology of Natural Substances: Foods, Fungi, Medicinal Herbs, Plants and Venomous Animals. John Wiley \& Sons Inc., Hoboken, Chapter 140.

[3] Joubert, P.H., Brown, J.M., Hay, I.T. and Sebata, P.D. (1984) Acute Poisoning with Jatropha curcas (Purging Nut Tree) in Children. South African Medical Journal, 65, 729-730.

[4] Marks, C.J. and van Hoving, D.J. (2016) A 3-Year Survey of Acute Poisoning Exposures in Infants Reported in Telephone Calls Made to the Tygerberg Poison Information Centre, South Africa. South African Journal of Child Health, 10, 43-46. https://doi.org/10.7196/SAJCH.2016.v10i1.1045

[5] Van Wyk, B.-E., Van Heerden, F.R. and Van Oudtshoorn, B. (2002) Poisonous Plants of South Africa. Briza Publications, Pretoria.

[6] Mampane, K.J., Joubert, P.H. and Hay, I.T. (1987) Jatropha curcas. Use as a Traditional Tswana Medicine and Its Role as a Cause of Acute Poisoning. Pharmacological Research, 1, 50-51. https://doi.org/10.1002/ptr.2650010112

[7] Wanzala, W. and Wanjala, C.C.W. (2016) Discovering Poisonous Plants by Tasting: The Case of Children in Mumias Sub-County, Kenya. Arabian Journal of Medicinal and Aromatic Plants, 2, 99-110.

[8] Pocock, S.J., Collier, T.J., Dandreo, K.J., et al. (2004) Issues in the Reporting of Epidemiological Studies: A Survey of Recent Practice. BMJ, 329, 880-883. https://doi.org/10.1136/bmj.38250.571088.55

[9] Kosam, A. and Nahrel, R. (2014) Clinical Profile of Jatropha curcas Poisoning in Children. International Journal of Medical Research and Review, 2, 221-227. 
https://doi.org/10.17511/ijmrr.2014.i03.12

[10] Levin, Y., Sherer, Y., Bibi, H., Schlesinger, M. and Hay, E. (2000) Rare Jatropha multifida Intoxication in Two Children. Journal of Emergency Medicine, 19, 173-175. https://doi.org/10.1016/S0736-4679(00)00207-9

[11] Ribeiro, S.S., et al. (2012) Chemical Constituents of Methanolic Extracts of Jatropha curcas L and Effects on Spodoptera frugiperda (J. E. Smith) (Lepidoptera: Noctuidae). Química Nova, 35, 2218-2221. https://doi.org/10.1590/S0100-40422012001100022

[12] Alexander, Z.-H., Rommel, Z.-H., Sergio, G.-L., Ernesto, Z.-F., Jorge, G.-B., Angel, C.-S., Carlos, P.-M. and Granara, A.A. (2016) Study on Inflammation and the Nervous System of Ethanol Extract of Jatropha curcas Seed. Pharmacognosy Journal, 8, 335-340. https://doi.org/10.5530/pj.2016.4.5

[13] Langrand, J., Médernach, C., Schmitt, C., Blanc-Brisset, I., Villa, A.F., de Haro, L. and Garnier, R. (2015) Intoxications par pignons d'Inde (Jatropha curcas): 24 observations rapportées aux centres antipoison de Paris et Marseille [Poisoning with Jatropha curcas: 24 Cases Reported to Paris and Marseille Poisons Centers]. Bulletin de la Société de Pathologie Exotique, 108, 139-143.

https://doi.org/10.1007/s13149-014-0412-3

[14] Koltin, D., Uziel, Y., Schneidermann, D., Kotzki, S., Wolach, B. and Fainmesser, P. (2006) A Case of Jatropha multifida Poisoning Resembling Organophosphate Intoxication. Clinical Toxicology (Philadelphia, Pa.), 44, 337-338. https://doi.org/10.1080/15563650600584584

[15] Singh, R.K., Singh, D. and Mahendrakar, A.G. (2010) Jatropha Poisoning in Children. Medical Journal Armed Forces India, 66, 80-81.

https://doi.org/10.1016/S0377-1237(10)80106-6 